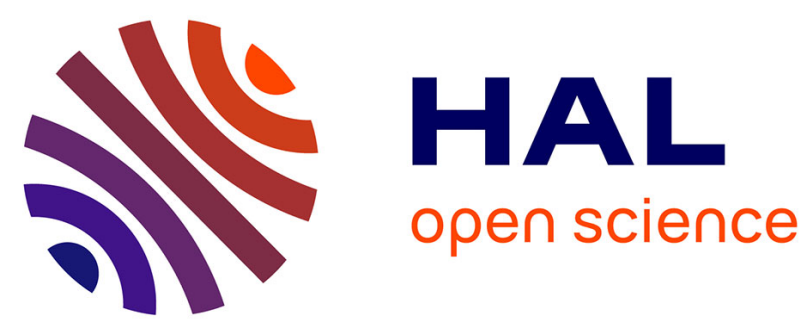

\title{
POST SINTERING HEAT TREATMENTS AND CREEP OF Si-Y-Al-O-N CERAMICS
}

Thierry Chartier, J. Besson, P. Goursat, W. Mustel

\section{To cite this version:}

Thierry Chartier, J. Besson, P. Goursat, W. Mustel. POST SINTERING HEAT TREATMENTS AND CREEP OF Si-Y-Al-O-N CERAMICS. Journal de Physique Colloques, 1986, Thirteenth International Conference on Science of Ceramics 47 (C1), pp.C1-673-C1-678. 10.1051/jphyscol:19861103 . jpa00225498

\section{HAL Id: jpa-00225498 https://hal.science/jpa-00225498}

Submitted on 1 Jan 1986

HAL is a multi-disciplinary open access archive for the deposit and dissemination of scientific research documents, whether they are published or not. The documents may come from teaching and research institutions in France or abroad, or from public or private research centers.
L'archive ouverte pluridisciplinaire HAL, est destinée au dépôt et à la diffusion de documents scientifiques de niveau recherche, publiés ou non, émanant des établissements d'enseignement et de recherche français ou étrangers, des laboratoires publics ou privés. 


\title{
POST SINTERING HEAT TREATMENTS AND CREEP OF Si-Y-AI-O-N CERAMICS
}

\author{
T. ChARTIER, J.L. BESSON, P. GOURSAT ${ }^{*}$ and W. MUSTEL * * \\ LA C.N.R.S. 320, E.N.S.C.I., 47, Avenue Albert Thomas, \\ F-87065 Limoges Cedex, France \\ *LA C.N.R.S. 320, U.E.R. des SCiences, 123, Avenue Albert \\ Thomas, F-87060 Limoges Cedex, France \\ * CERAVER, Usine de Buzet, B.P. 113, F-65001 Tarbes, France
}

Résumé - Sur deux nuances de céramiques de type SiYAloN, obtenues par frittage naturel, il est montré l'intérêt, pour améliorer la résistance au fluage, de traitements thermiques en lit de poudre sous atmosphère d'azote.

\footnotetext{
Abstract - For two batches of pressureless sintered SiYAION ceramics, it is demonstrated that the creep resistance may be improved by using powder bed heat treatments in nitrogen atmosphere.
}

\section{I - INTRODUCTION}

It is now well established that the high temperature behaviour of nitrogen ceramics is linked to the properties of the residual intergranular phase, i.e., to the nature and quantity of densification aids and to the metallic impurities in the raw materials. This intergranular phase may be modified by post-sintering heat treatment in oxidizing or neutral atmospheres $/ 1 /$. These possibilities have been illustrated by the study of the creep behaviour of two SiYAION materials with the same nominal ccmposition, but with a different impurity content ( $\mathrm{Ca}, \mathrm{Fe})$.

\section{II - MATERIALS}

Two batches of samples (N3 and N5) were prepared from silicon, aluminium and yttria powders. The nominal composition is the same, except for the purity of the silicon powder (Table 1). The powders are mixed in alcoohol, dried, then nitrided during a 70 hour thermal cycle. The reaction kinetics are controlled by nitrogen consumption /2/. The bricks are crushed and finely ground $(\phi<2 \mu \mathrm{m})$. After shaping, the samples are densified by pressureless sintering at $1700^{\circ} \mathrm{C}$ in nitrogen to $95 \%$ theoretical density. 


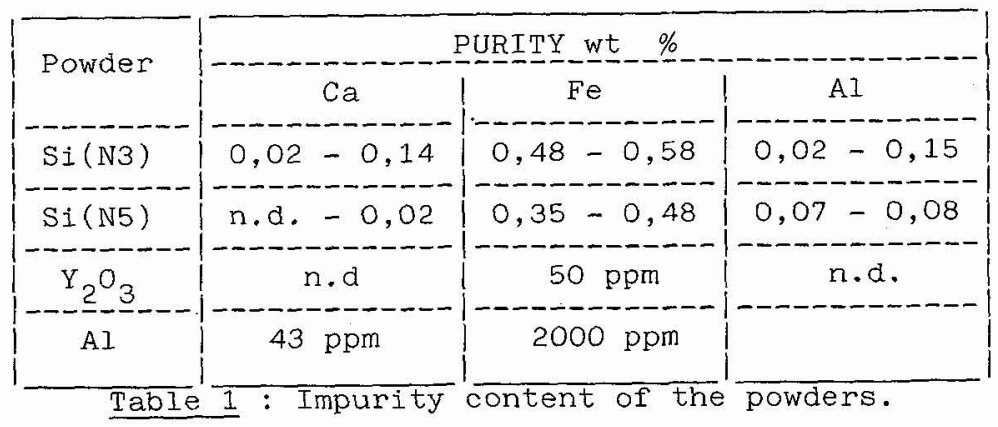

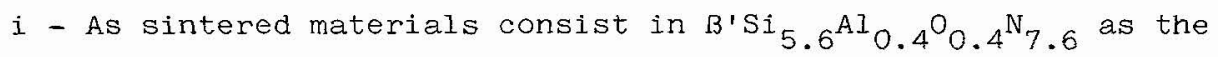
major phase, with a small amount of yttrium silicate ( $\mathrm{B}_{2} \mathrm{Si}_{2} \mathrm{O}_{7}$ ) and a rather large quantity of glassy phase (Fig. 1). No yttrium aluminium garnet has been detected either in $\mathrm{N}_{3}$ or $\mathrm{N}_{5}$ materials.

ii - After heat-treatment in air $\left(48 \mathrm{~h}-1350^{\circ} \mathrm{C}\right)$, microanalysis (E.D.A.X.) reveals a migration of calcium and yttrium which concentrate in the oxide scale at the external interface. T.E.M. micrographs show a partial microcrystallization of the glassy phase pockets (Fig. 2).

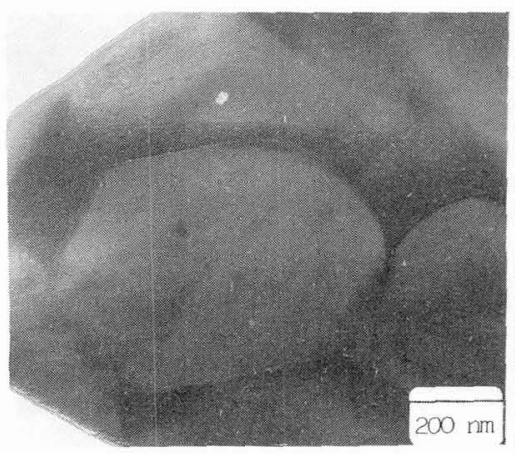

a

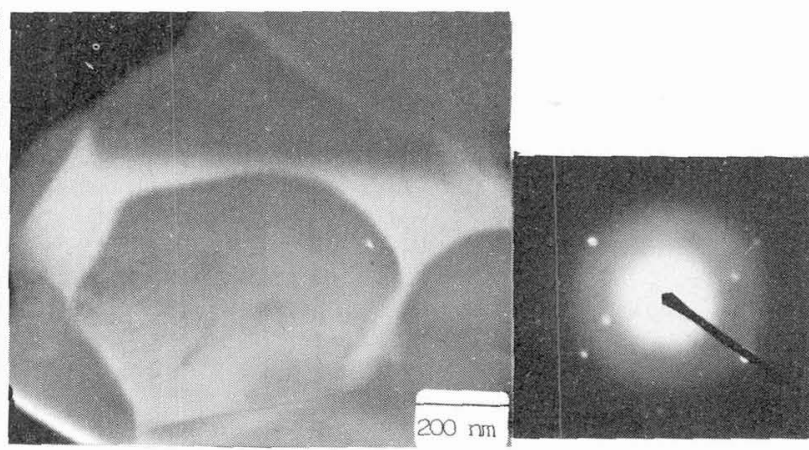

b

Fig. 1 : T.E.M. micrographs of as-sintered material. a - bright field, b - dark field and associated diffraction pattern.

iii - Heat-treatments have also been performed in a powder bed. The bars $\left(4 \times 4 \times 25 \mathrm{~mm}^{3}\right.$ ) are embedded in silicon nitride powder (purity $99.9 \%$ ) and treated in nitrogen for 100 hours at temperatures between 1150 and $1300^{\circ} \mathrm{C}$. A complete recrystallization of the glassy phase is evidenced by lack of any alteration under the electron beam during TEM investigation ( $f i g .3$ ). X-Ray diffraction patterns show an increase in $\mathrm{Y}_{2} \mathrm{Si}_{2} \mathrm{O}_{7}$ and the appearance of $\mathrm{AlYO}_{3}$ and of new phases which have not yet been identified. No outward ${ }^{3}$ diffusion of yttrium was detected by EDAX microanalyses of the sample surface. 


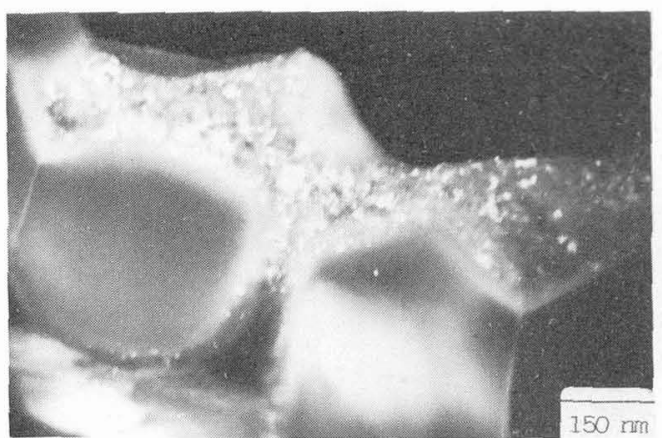

a

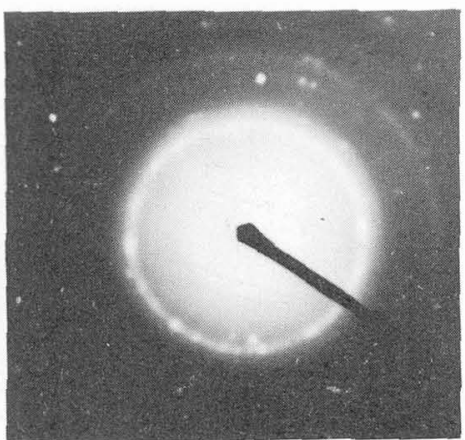

b

Fig. 2 : T.E.M. micrographs of a sample oxidized $48 \mathrm{~h}$ at $1350^{\circ} \mathrm{C}$. a - dark field, b - spotted rings in the diffraction pattern.

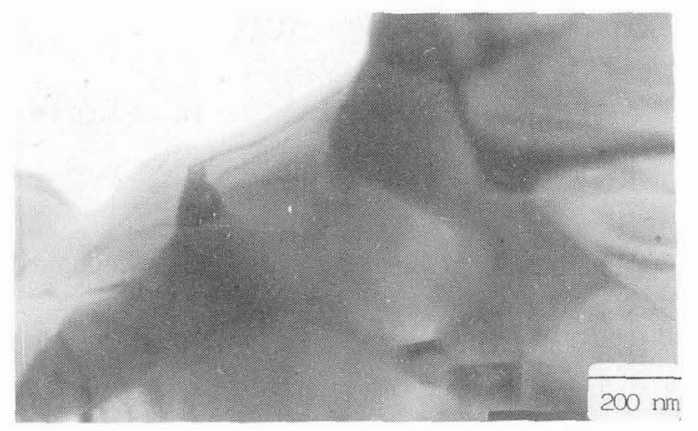

Fig. 3 : T.E.M. micrograph of a sample heat-treated in a powder bed.

\section{III - CREEP}

The 3-point bending creep tests in air are performed between 1100 and $1250^{\circ} \mathrm{C}$ at stresses ranging from 70 to $165 \mathrm{MPa}$. The stress and strain at the outermost fibre are calculated under elastic theory assumptions. This approximation is justified by the low value of the measured deflection and the newtonian behaviour of the flow in the stationary stage /3/. Typical creep curves are shown in figure 4. After a rapid decrease at the beginning, the creep rate continues to diminish slowly. A true steady state is reached only after several hundred hours. A tertiary creep has never been observed under our experimental conditions.

$i$ - Creep of the as-sintered $N_{3}$ material has been studied using the phenomenological relation $\dot{\varepsilon}=A(S)$ o $\exp -E / R T$ where $\dot{\varepsilon}$ is the creep rate at the outer tensile fibre, o the maximum tensile stress, $n$ the stress exponent, E the apparent activation energy, $R$ the Boltzmann constant, $\mathrm{T}$ the absolute temperature and $\mathrm{A}(\mathrm{S})$ a factor depending on the microstructure.

Determination of $n$, through stress-steps experiments, shows a linear and reversible variation of in $\dot{\varepsilon}$ versus in $\sigma$ for times greater than 340 hours (fig. 5). During the long preceeding period when the creep rate is slowly decreasing, the microstructure changes due to the oxidation and the decrease in quantity of the intergranular glassy 


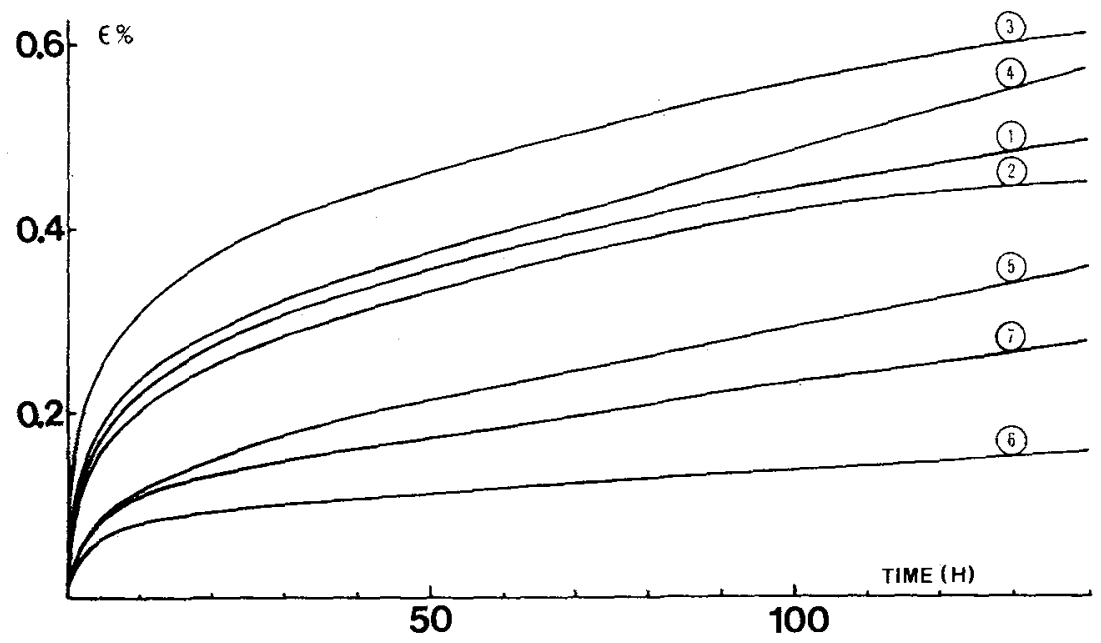

Fig. 4 : Creep curves at $1150^{\circ} \mathrm{C}$ and 120 MPa for $\mathrm{N}_{3}$-samples and $1200^{\circ} \mathrm{C}-$ $240 \mathrm{MPa}$ for $\mathrm{N}_{5}$-samples.

1 - as sintered $\mathrm{N}_{3}, 2-$ as sintered $\mathrm{N}_{5}$
2 - preoxidized $N_{3}\left(48 \mathrm{~h}-1350^{\circ} \mathrm{C}\right)$

$N_{5}$-samples heat-treated in a powder bed at

$4-1150^{\circ} \mathrm{C} ; 5-1200^{\circ} \mathrm{C} ; 6-1250^{\circ} \mathrm{C} ; 7-1300^{\circ} \mathrm{C}$.

phase (fig. 6). This oxidation leads to an outward migration of yttrium and calcium /4/. Studies of the oxidation behaviour have allowed us to link the onset of the stationary stage with an

intergranular oxidation completed in the bulk of the samples. At this stage, the evolution of the microstructure is achieved; the contribution of the viscoelastic effects to the creep rate becomes negligeable ; the only remaining mechanism is a diffusional one $(\mathrm{n}=1, E=780 \mathrm{~kJ} / \mathrm{mol})$. This mechanism corresponds to a solutionmigration-precipitation process induced by chemical potential gradients which arise from the buttressing of adjacent grains on ledges along grain-boundaries.

ii - N5 material shows a similar behaviour with a better resistance (fig. 4). The steady stage is reached more rapidly. The lower calcium and iron contents increase the refractoriness of the glassy phase.

iii - For N3 pre-oxidized samples also, the stationary stage is observed for shorter times than in as-sintered N3 samples, but the steady creep rate is higher (fig. 4). After creep test, no noticeable microstructural changes have been observed, which means that the microstructure has been stabilized by the oxidation treatment. A consequence of the partial microcrystallization of the glassy phase pockets may be that the solution-migration-precipitation process can now occur at buttressing points between crytallites. This possibility of matter flow between silicate crystallites through the oxidized residual glassy phase might explain a higher value for the creep rate in the steady-state creep. 


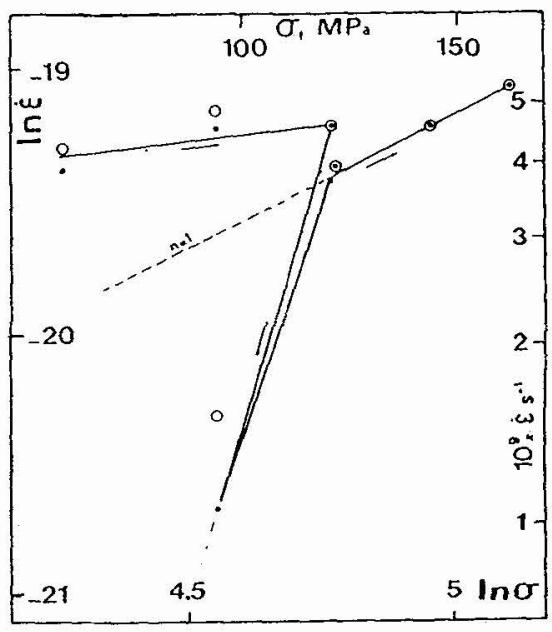

Fig. 5

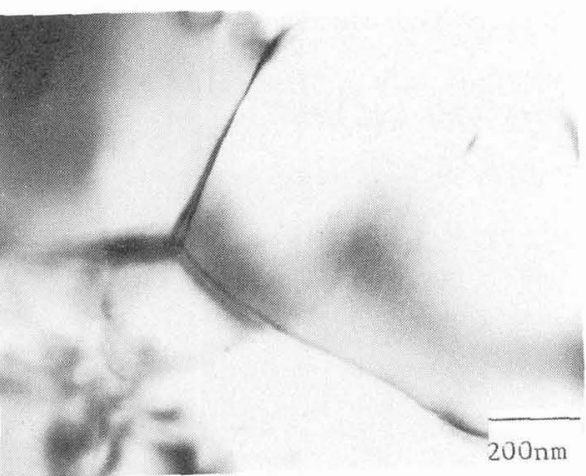

Fig. 6

Fig. 5: Creep rate at $1150^{\circ} \mathrm{C}$ versus stress for as-sintered $\mathrm{N}_{3}$-samples.

Fig. 6 : T.E.M. micrograph of $\mathrm{N}_{3}$-sample after creep.

i.v - After treatment in a powder bed at $1150^{\circ} \mathrm{C}$, the behaviour is similar, to that of the as-sintered material, but improves with increasing heat treatment temperature. In the case of a sample heat treated at $1250^{\circ} \mathrm{C}$, the steady state creep rate is lower and the strain is three times less than in the case of the as-sintered material, all else being equal. This improvement is ascribed to the crystallization leading to the almost complete disappearance of the vitrous phase. The powder bed protects the samples from any decomposition and for reaction with oxygen traces in the atmosphere.

\section{IV - CONCLUSION}

This study demonstrates that the difference in behaviour between the two SIYAION materials, N3 and N5, of the same nominal composition, is related to their different calcium impurity contentis ; iron does not seem to play any role. Thermal treatments either in oxidizing or neutral atmospheres, lead to the crystallization, more or less complete, of the secondary glassy phase. In oxidizing environments, surface pitting limits the duration of the treatment, whereas in the case of the powder bed technique, the samples are protected from surface degradation and reach the stable thermodynamical state characterized by the elimination of the transient glassy phase.

For this SiYAION ceramic, heat treatments in nitrogen using a powder bed induce a marked improvement in the creep resistance. 


\section{REFERENCES}

/1/ BESSON J.I., BOUARROUDJ A. and GOURSAT P. - ReV. Int. Hautes Tempér. Refract., 19 (1982), 381.

/2/ MUSTEL W. and BROUSSAUD D. - "Science of Ceramics 12", edited by P. Vincenzini Ceramurgia publisher (1983), p. 131 .

/3/ HOLLENBERG G.W., TERWILLIGER G.R. and GORDON R.S. - J. Am. Ceram. Soc. $54(1971) 196$.

14/ CHARTIER T. - Thèse Docteur Ingénieur, Limoges (1985). 